\title{
Accountability Through Fact-Finding: Appraising Inquiry in the Context of Srebrenica
}

\author{
Larissa van den Herik ${ }^{1}$
}

Published online: 14 August 2015

(C) The Author(s) 2015. This article is published with open access at Springerlink.com

\begin{abstract}
The Srebrenica tragedy has given rise to many responses of political, judicial and semi-judicial nature. One mechanism that has perhaps received less attention than the adjudicatory performances is the institution of inquiry. This article contrasts the two most prominent formal inquiries into the fall of Srebrenica by the UN and the Dutch NIOD and it offers valuable insights into the role and authority of inquiry exercises regarding international affairs and moments of crisis. The article also examines the function of ex post facto inquiries as compared to judicial exercises. Given that inquiry processes generally establish a greater set of facts which are not tied up to legal categories, it is argued that the institution of inquiry may fulfil a complementary function to legal processes as it can offer a more comprehensive account of events and thus address societal demands for the accountability of a wider range of actors.
\end{abstract}

Keywords Inquiry · Fact-finding $\cdot$ NIOD report $\cdot$ Srebrenica $\cdot$ United Nations

\section{Introduction}

On 11 July 1995, the enclave of Srebrenica was taken without any effective international resistance or comprehensive protection efforts. The absence of candid action during the fall of Srebrenica contrasts sharply with the multitude of reactions thereafter. The myriad of responses were spread out over a significant amount of time, up to two decades. They were of a political, judicial and semi-judicial nature,

Prof. Dr. Larissa van den Herik is Vice Dean of the Law Faculty of Leiden University and Professor of Public International Law at the Grotius Centre for International Legal Studies.

Larissa van den Herik

L.van.den.Herik@LAW.leidenuniv.nl

$1 \quad$ Leiden, The Netherlands 
and they all shared comparable moral undertones. ${ }^{1}$ One relevant mechanism has perhaps received less attention than the adjudicatory performances. This is the institution of inquiry. In fact there have been multiple fact-finding exercises into the fall of Srebrenica, both international as well as domestic in nature and of both a formal as well as an informal character. ${ }^{2}$

This contribution zeroes in on the method of inquiry as a response to the fall of Srebrenica. It singles out two formal inquiries that have been the most prominent: the UN inquiry and the inquiry by the Nederlands Instituut voor Oorlogsdocumentatie (NIOD) [the Dutch Institute for War Documentation]. ${ }^{3}$ The international UN inquiry was policy-driven and diplomatic in nature, ${ }^{4}$ while the domestic Dutch undertaking had a more historical and scientific orientation. ${ }^{5}$ Comparing the two offers valuable insights into the role and authority of inquiry exercises regarding international affairs and moments of crisis. This article thus endeavours to provide some understanding of factors that are relevant to shaping the authority of inquiry

\footnotetext{
${ }^{1}$ Judicial responses took place within different jurisdictions. At the ICJ, the central case was Application of the Convention on the Prevention and Punishment of the Crime of Genocide (Bosnia and Herzegovina v. Serbia and Montenegro), Judgement of 26 February 2007. The most important Srebrenica litigation at the ICTY took place in the cases of The Prosecutor v. Karadžić, Case No. IT-95-5/18, judgement expected in December 2015; The Prosecutorv. Mladić, Case No. IT-09-92; The Prosecutorv. Krstić, Case No. IT-98-33, Appeals Judgement on 19 April 2004; The Prosecutor v. Blagojević and Jokić, Case No. IT-02-60, Appeals Judgement on 9 May 2007; The Prosecutor v. Tolimir, Case No. IT-05-88/2, Appeals Judgement on 8 April 2015; The Prosecutor v. Popovic et al., Case No. IT-05-88, Appeals Judgement on 30 January 2015; and the case The Prosecutor v. Orić, Case No. IT-03-68, Appeals Judgement on 3 July 2008. Relevant domestic litigation occurred in the Netherlands in the civil cases of Nuhanović and Mustafic et al., and Mother of Srebrenica, as well as in the Karremans criminal complaints case, cf. Art. 12 of the Dutch Code of Criminal Procedure, see: Supreme Court of the Netherlands (Hoge Raad), State of the Netherlands v. Mustafic et al., 6 September 2013, ECLI:NL:HR:2013:BZ9228; Supreme Court of the Netherlands (Hoge Raad), State of the Netherlands v. Nuhanović, 6 September 2013, ECLI:NL:HR:2013:BZ9225. Supreme Court of the Netherlands (Hoge Raad), Mothers of Srebrenica et al. v. State of the Netherlands, 13 April 2012, ECLI:NL:HR:BW1999, and District Court of The Hague, Mothers of Srebrenica et al. v. State of the Netherlands, 16 July 2014, ECLI:NL:RBDHA:2014:8562; Court of Appeal of Arnhem-Leeuwarden, Mehida Mustafić-Mujić et al. v. Karremans et al., 29 April 2015, ECLI:NL:GHARL:2015:2968. See also the other contributions in this special issue.

${ }^{2}$ Formal inquiries include: Report of the Secretary-General pursuant to General Assembly Res. 53/35, UN Doc. A/54/549, 15 November 1999; Report of the Panel on United Nations Peace Operations (Brahimi report), UN Doc. A/55/305-S/2000/809, 21 August 2000; NIOD (2002). Parliamentary inquiries include: Missie zonder vrede. Enquête Srebrenica [Dutch Parliamentary Inquiry] (chaired by Bert Bakker), Tweede Kamerstuk 28 506, nr. 3, 2002-2003; Rapport d'information déposé par la mission d'information commune sur les événements de Srebrenica, Enregistré à la Présidence de l'Assemblée Nationale, 22 November 2001. Informal inquiries e.g., by non-governmental organisations (NGOs) include: The Fall of Srebrenica and the failure of UN peacekeeping in Bosnia and Herzegovina, Human Rights Watch, Vol. 7, No. 13, October 1995. Human rights reporting includes: Situation of human rights in the territory of the former Yugoslavia, ECOSOC, periodic report submitted by Mr. Tadeusz Mazowiecki, Special Rapporteur of the Commission on Human Rights, E/CN.4/1996/6, 5 July 1995 and the report submitted by Ms. Elisabeth Rehn, Special Rapporteur on the Commission on Human Rights, E/CN.4/1996/63, 14 March 1996.
}

3 As indicated in the previous footnote, the French inquired into the fall of Srebrenica through a parliamentary commission, which is a different exercise than an independent inquiry and is therefore not addressed in this essay.

${ }^{4}$ Report of the Secretary-General pursuant to General Assembly Res. 53/35 (hereafter UN Srebrenica report), UN Doc. A/54/549, 15 November 1999, para. 5.

5 NIOD (2002), p. 10. 
findings and their reports and to shed some light on the function of ex post facto inquiries as compared to judicial exercises. As an integral part of this twofold purpose, the article also highlights how the two inquiries, which are inherently supposed to be fact-finding exercises, engaged with certain questions of international law and how this engagement was informed by their function.

The article is structured as follows. Section 1 introduces the concept of inquiry and differentiates between types of inquiries and their respective functions. It typifies both Srebrenica inquiries as being retrospective. Sections 2 and 3 then zero in on the UN and Dutch inquiry respectively. Section 4 offers a brief comparative analysis on the political and judicial reception of the respective UN and NIOD findings and Sect. 5 concludes with some more generic observations on the institution of inquiry in the contemporary international legal order.

\section{Inquiry in International Law}

International fact-finding has a long history in international law. The concept of inquiry was introduced in the international society by the Russian diplomat Friedrich Martens during The Hague peace negotiations of 1899 and $1907 .^{6}$ While initially designed as a purely fact-oriented inter-state dispute settlement mechanism that would either pre-empt any further escalation of a conflict or be conducive to mediation and conciliation initiatives, over time international commissions of inquiry came to perform a great variety of functions, including with a more legal orientation, in different institutional settings and for different purposes. ${ }^{7}$

Today, the most notable commissions of inquiry are those established by the Human Rights Council. These commissions do not resemble their Hague predecessors at all. In contrast to the archetypical Hague Commissions, the human rights commissions of inquiry do not primarily aim to pacify and resolve disputes. Instead, these commissions set out to alert the international community of ongoing atrocities and human rights violations. In line with their mandate and their 'alert function', human rights commissions of inquiry tend to frame their most crucial findings as violations of international law rather than as findings of fact. The underlying presumption and strategy thereof is that such framing more promptly evokes a response or corrective action. ${ }^{8}$ As such, human rights commissions of inquiry have moved beyond mere fact-finding and they engage with international law quite expressly and purposefully. Such engagement remains without any binding legal consequences though, while it does often have great moral or political effect. It is effectively meant to borrow and rely on the authority of law.

In addition to the human rights commissions of inquiry, other types of inquiry commissions still exist and function in parallel and distinct settings. For instance, there are technical commissions of inquiry which find their basis in specialized treaty regimes. Those technical commissions have remained more loyal to the

\footnotetext{
${ }^{6}$ See for a historical overview of inquiry in international law, Van den Herik (2014).

7 Ibid.

8 Van den Herik and Harwood (2015) (forthcoming).
} 
Hague archetype. Examples of treaties that provide for inquiry as a modality of dispute settlement beyond the setting of human rights and peace and security are the 1991 Convention on Environmental Impact Assessment in a Transboundary Context and the 1997 Convention on the Law of Non-navigational Uses of International Watercourses. In addition, fact-finding occurs as part of verification missions in the context of arms control regimes. These are mostly done through on-site inspections, e.g., within the framework of the International Atomic Energy Agency, the 1993 Chemical Weapons Convention, or the 1997 Ottawa Convention on Anti-Personnel Mines. Generally the mandate of these commissions is to establish certain non-legal 'empirical facts' with a view to settling a given dispute or verifying certain claims. They are thus less law-oriented. In particular constellations, these technical commissions of inquiry are even expressly prohibited from drawing any conclusions with a legal dimension, and most notably they can be barred from making normative findings related to questions of responsibility. An example thereof is the inquiry procedure under the International Convention for Civil Aviation (Chicago Convention), which has as its exclusive aim to prevent future aviation accidents. ${ }^{9}$

Beyond this host of specific inquiry mechanisms, there is no universal, allencompassing commission of inquiry generally empowered to engage in factfinding whenever the need arises. The theme-specific approach comports with the current architecture of the international legal order. Even the centralization of the power to maintain international peace and security in the Security Council has not been accompanied by the establishment of a centralized security fact-finding agency. Thus far, international decision-making in situations of conflict and other threats to the peace has remained largely dependent on information presented by individual states. The absence of such a universal or centralized body has at times undermined the credibility, authority and stability of the whole collective security system whose proper functioning hinges on the establishment of accurate factual information and a shared appreciation and evaluation of facts. For instance and as witnessed in the situation of Syria, the contestation of facts can contribute to a stalemate within the Security Council. On other occasions, the Security Council has acted on the basis of misinformation, such as the claims regarding the presence of weapons of mass destruction in Iraq (2003) and the attribution of the Madrid terrorist attacks to ETA (2004). ${ }^{10}$ Commissions of inquiry can-to some extentprevent such mishaps and fulfil an investigative or diagnostic function and thus offer a basis for informed decision-making.

\footnotetext{
9 Art. 26 of this Convention reads: 'In the event of an accident to an aircraft of a contracting State occurring in the territory of another contracting State, and involving death or serious injury, or indicating serious technical defect in the aircraft or air navigation facilities, the State in which the accident occurs will institute an inquiry into the circumstances of the accident, in accordance, so far as its laws permit, with the procedure which may be recommended by the International Civil Aviation Organization. The State in which the aircraft is registered shall be given the opportunity to appoint observers to be present at the inquiry and the State holding the inquiry shall communicate the report and findings in the matter to that State'. Interestingly, Annex 13 to the Convention specifies in Standard 3.1 that, 'the sole objective of investigation of accidents or incidents shall be the prevention of accidents or incidents. It is not the purpose of this activity to apportion blame or liability'. In the Netherlands the Onderzoeksraad voor Veiligheid [Dutch Safety Board] implements this obligation, e.g., in relation to the downing of the MH17.

${ }^{10}$ UN Security Council Resolution 1530, 11 March 2004.
} 
On the basis of the above, a differentiation can be made between different types of inquiries on the basis of subject-matter. Temporal considerations can form an alternative basis for differentiation as some commissions operate ex ante with a view to informing or prompting decision-making while other commissions perform retrospective functions. Commissions of inquiry that operate in the aftermath of a given incident or conflict situation often have mandates with educational and truthseeking underpinnings. They may also be expressly geared towards questions of accountability or have a mission of exposure.

The Srebrenica inquiries are both examples of this retrospective type, albeit that each inquiry had a slightly distinct purpose and mandate and operated in discrete settings. These variances translated into different outcomes and emphases. To some extent, retrospective formal fact-finding exercises are comparable to NGO examinations, journalistic accounts and even the publication of monographs by politicians and other involved individuals. ${ }^{11}$ All these initiatives share the objective to enlighten and explain, and perhaps even more to reveal. On a sliding scale, reports of fully external actors, and possibly in particular NGOs, tend to be more inspired by naming-blaming-shaming dynamics, whereas at the other end of the spectrum, State-initiated inquiries are often rather meant to stimulate a certain introspection. More cynically, state-sponsored inquiries can also be intended or perceived as attempts to dilute or circumvent responsibility. ${ }^{12}$ Yet, the main difference between formal and informal fact-finding may be the relevant audience. Formal fact-finding exercises are, at least officially, bound by their mandate and they report principally to their parent body, even though they do have wider radiation and are of course aware thereof. Informal fact-finders have at best informal ties to formal authorities and in addition to policymakers, their primary audience will often be the 'court of public opinion'.

Beyond their formality, the function of commissions of inquiry and the authority of their findings still depend on the greater spectrum of politics and expectations in which they operate and of which they form part. In addition to those externalities, the status of the parent body, the mandate, the working methods, procedures and composition of commissions as well as the contents of an inquiry report may also be determinant for its reception. The following two sections analyse and contrast the two most prominent Srebrenica inquiries, i.e. the UN inquiry and the Dutch inquiry, to explore how the setting in which they operated influenced their findings. A subsequent section offers some insights into the political and judicial reception of their reports and reflects on their respective authority.

\footnotetext{
11 See e.g., Hartmann (2015), Voorhoeve (2015).

12 See e.g., the concerns expressed by MSF in relation to the French Parliamentary inquiry, MSF, Parliamentary inquiry of Srebrenica-Investigation or diversion, 11 November 2000, para. 5. The concerns related, inter alia, to the appointment of former Defence Minister Léotard who was in office during the Fall of Srebrenica. Recognizing the potential of inquiries to function as de facto shielding exercises, the Secretary-General pre-empted such critiques and expressly indicated that he 'in no way sought to deflect criticism directed at the United Nations Secretariat'.
} 


\section{The UN Inquiry}

Rwanda 1994 and Srebrenica 1995 are two great moments of shame and failure of the international community and the United Nations specifically. The UN's action, or in fact its inaction, is recorded in two inquiry reports that were issued on 15 and 16 December 1999 for Srebrenica and Rwanda respectively. Interestingly, the Rwanda inquiry was initiated by the Secretary-General ${ }^{13}$ and endorsed by the Security Council, while the Srebrenica inquiry originated in a request from the General Assembly. ${ }^{14}$ Subsequent to the creation of those two situation-specific inquiries, Secretary-General Annan also established a more comprehensive and thematic panel to assess the UN's overall ability to conduct peace operations. This high-level panel was chaired by Lakhdar Brahimi.

The principal instruction for the high-level panel chaired by Brahimi was to assess 'the shortcomings of the existing system' and to formulate 'frank, specific and realistic recommendations for change'. ${ }^{15}$ The emphasis of the mandate was thus forward-looking. In contrast, the Rwanda and Srebrenica inquiries were predominantly retrospective in nature. The primary purpose of these independent inquiries was 'to establish the facts and to draw conclusions as to the response of the Organization to the tragedy', ${ }^{16}$ and 'to explain why the United Nations failed'. ${ }^{17}$

Specifically, the UN Srebrenica inquiry aimed at scrutinizing the background of the failure of the safe area policy with a view to 'illuminate the process by which the United Nations found itself, in July 1995, confronted with these shocking events'. Within this setting, the purpose of the inquiry was twofold. It engaged with issues of responsibility for the fall of Srebrenica specifically and it was meant to be a lessonslearnt exercise on how international responses to conflicts should be formulated, given shape and implemented. ${ }^{18}$ Even more concretely, it was hoped that through the inquiry lessons could be drawn regarding the failed safe area policy. The inquiry was premised on the idea that the United Nations shared responsibility with others and that lessons were to be learnt both by the Secretariat as well as by Member States. Yet, the inquiry's account was principally given from a United Nations perspective. $^{19}$

This focus on the United Nations was corroborated by the selected methodology of relying predominantly on archival research within the UN system, complemented by interviews. ${ }^{20}$ Exceptionally, some classified files were entered in the public record. Yet it was also noted that the United Nations had not disclosed the full details of the attack on Srebrenica, and the report's account of the attack was

\footnotetext{
13 UN Doc. S/1999/339, 26 March 1999 and UN Doc. S/1999/340, 26 March 1999.

14 UNGA Res. 53/35, 30 November 1998.

15 UN Brahimi report, para. 2.

16 Letter dated 18 March 1999 from the Secretary-General addressed to the President of the Security Council, UN Doc. S/1999/339, 26 March 1999.

17 UN Srebrenica report, para. 3.

18 UN Srebrenica report, para. 5.

19 UN Srebrenica report, para. 7.

${ }^{20}$ UN Srebrenica report, para. 8.
} 
reconstructed mainly from Dutchbat reports and the Dutch debriefing process, complemented by other secondary sources and interviews. ${ }^{21}$ As regards the killings, the International Criminal Tribunal for the former Yugoslavia (ICTY) Prosecutor's files were a principal source of information. Early decisions in the cases against Mladić and Karadzić and the indictment against Krstić constituted the basis of the report's findings, but they were not expressly cited so as not to jeopardize the Tribunal's ongoing work. ${ }^{22}$ The principal author of the report was David Harland, a senior UN official who had been based in Bosnia during the events.

The overall tenor of the report is explicatory and it underlines the conceptual flaws of the safe area policy. It contextualizes the fall of Srebrenica and addresses the absence of air support during the fall. It also reports on the earlier hostage crisis of May-June 1995 during which over four hundred UN personnel were taken hostage by the Serbs and explains how this influenced ensuing events. The report engages with claims that the hostages had been released in exchange for an undertaking that no more air support would be used against the Serbs, but rejects those rumours. ${ }^{23}$ Yet, US documents released in 2013 did reveal that a decision not to use force had been made on 28 May 1995 by the UK, France and the US, i.e., during the hostage crisis. ${ }^{24}$ Given the confidentiality of these documents at the time of the inquiry, they are missing from the UN report. The report thus left some significant facts uncovered on crucial questions regarding the omission to provide timely and adequate air support to prevent the fall of Srebrenica. On the issue of air support, the report reads,

Some sources approached in the context of this report indicated that the Dutchbat requested close air support at this time, or some earlier in the morning (of 10 July), because the warning to the Serbs had been violated. The request, if made, was not approved. It has not been possible to verify at what level the request was turned down, if at all, as there is no written record of it, and a number of the key personnel at each of the higher levels of command do not recall any request having been received at that time. ${ }^{25}$

While some facts were thus left unclear, other facts remained contested. One example is where the UN report states that the Dutchbat Commander, i.e. Karremans, had indicated that the blocking positions defending Srebrenica could still hold and that air support could wait until the next morning. ${ }^{26}$ The NIOD report explicitly questions this finding. ${ }^{27}$

Despite this contestation and even if the report does not capture all the relevant facts, it remains strongly fact- and policy-oriented. As a consequence, it does not directly engage with questions of legal responsibility and refrains from the use of

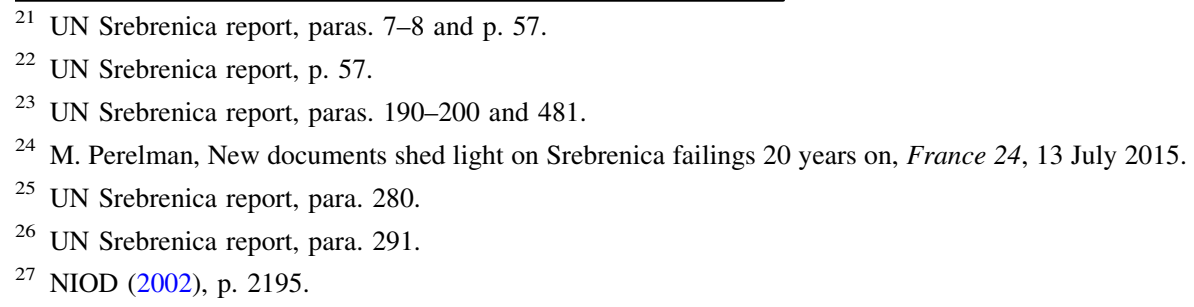


legal terms as much as possible. The background description of the Yugoslav breakup touches on some findings with normative implications but generally legal questions are circumvented. For instance, on Resolution 713, which established the legally challenged arms embargo, ${ }^{28}$ the report remarks that, 'several observers noted at the time that the major effect of the embargo would be to freeze the military holdings of each of the parties - a move which would overwhelmingly benefit the Serbs, who were dominant both in the Yugoslav military and, to a lesser extent in the arms industry'. ${ }^{29}$ In a similar vein, the legal classification of the conflict was outsourced to the ICRC. ${ }^{30}$ Yet, in other instances in the background description the report does make findings of a direct legal nature, e.g., when it holds that the Serb restriction of humanitarian aid was, apparently, not intended to starve the population. ${ }^{31}$ Yet, overall, the report is fact-focused rather than law-focused. Most intriguingly from a 2015 perspective and the commemorating Security Council Resolution that was blocked by Russia because it featured the word 'genocide', 32 the UN inquiry report of 1999 speaks only of an 'attempted genocide'. 33

As regards the evaluations and appraisals, it has been observed that the UN inquiry displayed, 'a degree of self-criticism (that) is rare for any large organization and particularly rare for the United Nations'. ${ }^{34}$ Indeed, the Special Representative's update on the situation in Srebrenica on 10 July was disqualified in the report as 'substantially inaccurate'. ${ }^{35}$ Even more straightforward was the judgement that the repeated public declarations that air power would only be used against the Serbs as a last resort were 'wrong', as was the acceptance of the daily shelling of the safe areas. ${ }^{36}$ Yet the appraisal of the involved Member States' actions and their inactions was at times evasive, which may have been inspired by diplomatic considerations.

The final assessment of Dutchbat's operation is balanced. It reads,

it is easy to say with the benefit of hindsight and the knowledge of what followed that the Netherlands battalion did not do enough to protect those who

\footnotetext{
${ }^{28}$ Resolution 713 was challenged by Bosnia before the ICJ. Bosnia held that the Security Council Resolution imposing an arms embargo upon the former Yugoslavia must not be construed in a manner that would not impair Bosnia and Herzegovina's right of self-defence. ICJ, Application of the Convention on the Prevention and Punishment of the Crime of Genocide, Provisional Measures, Order, 13 September 1993 and the separate opinion of Judge Lauterpacht, paras. 98-104.

29 UN Srebrenica report, para. 12, but see also para. 490 which states that the arms embargo was not necessarily a mistake, even if it effectively deprived the Republic of Bosnia and Herzegovina of its inherent right to self-defence.

${ }^{30}$ UN Srebrenica report, para. 16.

31 UN Srebrenica report, paras. 21 and 22. See for the relevant legal framework, Art. 54 of Additional Protocol I and Art. 14 of Additional Protocol II. More generally on Humanitarian Assistance, see the report of the Dutch Advisory Committee on Issues of Public International Law of August 2014, report No. 25, available at: http://www.cavv-advice.com.

32 UN Docs. S/2015/508 and S/PV.7481, 8 July 2015.

33 UN Srebrenica report, paras. 491, 501, 505. Interesting is the reference in para. 63 to a Security Council Missions document UN Doc. S/25700 which uses the word genocide more unreservedly.

34 UN Brahimi report, p. iii.

35 UN Srebrenica report, para. 282.

${ }^{36}$ UN Srebrenica report, para. 483.
} 
sought refuge in its compound. Perhaps the soldiers should have allowed everyone into the compound and then offered themselves as human shields to protect them. This might have slowed down the Serbs and bought time for higher-level negotiations to take effect. At the same time, it is also possible that the Serb forces would then have shelled the compound, killing thousands in the process, as they had threatened to do. Ultimately, it is not possible to say with any certainty that stronger actions by Dutchbat would have saved lives, and it is even possible that such efforts could have done more harm than good. $^{37}$

The only direct reproach that is being made towards Dutchbat personnel regards the failure to report on the 'sinister indications' of unfolding scenes after the enclave's fall. ${ }^{38}$ It thus seems that the report's criticisms primarily concern the UN as an institution, its safe area policy and the joint miscarriages regarding timely air support, rather than individual Member States and their officials.

\section{The NIOD Study}

Srebrenica became a national trauma for the Netherlands. It has led to several domestic inquiries. Dutchbat's Debriefings report in October 1995 did not respond to all queries that had arisen regarding the responsibilities of Dutch troops and the political leaders involved. Subsequently, when it appeared that some film material made by Dutch troops during the fall capturing the mass killings had been destroyed, new queries arose. As the public debate regarding the Dutch involvement in and the responsibilities for the fall of Srebrenica lingered on, the Dutch government decided in the summer of 1996 to launch an inquiry. ${ }^{39}$ Initially, the Dutch government believed that a comprehensive inquiry at the international level would provide the best insight. However, this idea did not resonate with other relevant States nor with implicated international organizations and these were reluctant to engage in such an exercise. ${ }^{40}$ Subsequently, therefore, the Dutch government requested the NIOD to investigate the events before, during and after the fall of Srebrenica against the background of the political and military situation in Bosnia-Herzegovina. This request was supported by a parliamentary majority, while a minority preferred a parliamentary inquiry. ${ }^{41}$ A decisive factor that made NIOD

\footnotetext{
37 UN Srebrenica report, para. 473.

38 UN Srebrenica report, para. 474.

39 NIOD (2002), p. 9. In 1998, a separate inquiry was launched into the disappearance of other film material and the broader questions whether the Ministry of Defence was cooperating sufficiently in reporting about the fall of Srebrenica. This inquiry was led by Van Kemenade. It concluded that the Ministry had indeed cooperated sufficiently, but did question the adequacy of the investigations into the misbehaviour of certain Dutch troops, Parliamentary Records TK 26122, nos. 5-6 (1998-1999), 28 September 1998.

40 NIOD (2002), prologue, p. 9.

41 Ibid.
} 
accept the mission was its perception of a Dutch societal desire for more clarity on what had happened in Srebrenica. ${ }^{42}$

The NIOD Srebrenica inquiry was unique in its type. Not only was its historic orientation different from other formal inquiry exercises regarding international affairs, but also from the perspective of the historical academic discipline, reporting on such recent events while the conflict was still ongoing and while new developments were unfolding was an unprecedented and perhaps even precarious exercise. ${ }^{43}$ Given that the situation in the former Yugoslavia was still in full flux, the Srebrenica assignment required innovative approaches which arguably trespassed accepted methods of research in contemporary history. ${ }^{44}$ For example, the NIOD report relied on materials of the ICTY Prosecutor while the criminal investigations were ongoing, and sometimes even before cases against specific accused had opened. $^{45}$

The specific assignment given to NIOD was to gather all relevant facts and on this basis to offer an insight from a historical perspective and in both a national and an international context into the causes and events surrounding the fall of Srebrenica and its aftermath. ${ }^{46}$ Specific elements mentioned that needed clarification included the UN concept of 'safe areas', the operation and command structure of the UN peacekeeping force, decision-making within the UN and NATO, Dutch decisionmaking and parliamentary involvement therein, the actions of Dutchbat, the question regarding air support, the blockade and seizure of Srebrenica and the acts of the Bosnian Serbs after the fall of the enclave. ${ }^{47}$ Hence, NIOD was faced with a complex web of questions that were each of a very distinct character and required different investigative expertise.

The inquiry was characterized as historical and scientific. ${ }^{48}$ The deadline given for the completion of the report was 'as soon as possible', ${ }^{49}$ but ultimately this turned out to be more than five years later. The report was presented to the Dutch government on 10 April 2002 and counted 3,368 pages. It offers a wealth of information. Yet, its comprehensiveness seems to be both its strength and its weakness. The report has been criticized for not offering any clear answers. ${ }^{50}$ Its wide breadth may even bestow it with a certain Wikipedian character offering an abundance of facts established in different ways and by different people. ${ }^{51}$ Indeed, where the principal author of the UN report, Harland, could offer a first-hand account with the authority of a person who lived through the conflict, and where he did so in a timely and concise manner, the NIOD investigators obtained their

\footnotetext{
${ }^{42}$ NIOD (2002), p. 10.

${ }^{43}$ Lagrou (2003), p. 328.

${ }^{44}$ Lagrou (2003), p. 328. See also the authors of the report in Blom and De Graaff (2003), p. 118.

${ }^{45}$ Lagrou (2003), p. 331.

${ }^{46}$ Parliamentary Records TK 25069, no. 1 (1996-1997), 18 October 1996.

${ }^{47}$ Parliamentary Records TK 25069, no. 1 (1996-1997), 18 October 1996.

48 Parliamentary Records TK 25069, no. 1 (1996-1997), 18 October 1996.

49 Parliamentary Records TK 25069, no. 1 (1996-1997), 18 October 1996.

${ }^{50}$ Runia (2015).

${ }^{51}$ Baudet (2003), pp. 16-17.
} 
assignment after the concrete events had already occurred, in November 1996, and they had to become acquainted with the conflict and the happenings ex post facto. As historians, the methodological starting point was a literature study. ${ }^{52}$ This was complemented with interviews. A number of factors affected the methods chosen and complicated access to sources. Firstly, as regards the method, interviewing in conflict zones, and particularly the interviewing of individuals who are possibly implicated in crimes, requires special expertise which might go beyond regular historical research. More generally, as regards interviewing techniques, the report observed that interviewing under oath is not an instrument belonging to the contemporary-historical researcher. ${ }^{53}$ This instrument is used for criminal or parliamentary investigations which lead to decisions on responsibility affecting concrete individuals. Historical research has a different aim, namely to obtain an insight which is as comprehensive and complete as possible in a given episode. ${ }^{54}$

A second complicating factor related to access to sources, as key individuals such as Mladić and Karadzić were not available for the NIOD investigators. NIOD also explicitly regretted the refusal of the French Generals to cooperate, including General Janvier, the Force Commander of UNPROFOR during the fall. ${ }^{55}$ Similarly, NIOD was denied access by the Dutch government to the 1995 Debriefing declarations. ${ }^{56}$ The Dutch government, and particularly the Ministry of Defence, emphasized the importance of a strong disconnection between the debriefing and potential investigations into criminal acts. ${ }^{57}$ Interestingly, according to the Dutch Court of Appeal in the criminal complaints case against Karremans, the interests of the Ministry of Defence in an optimal debriefing had perhaps too excessively outweighed the interests of justice. ${ }^{58}$ As noted by NIOD, the ICTY was eventually granted access to all Debriefing files by the Dutch government. This difference in treatment between NIOD and the ICTY can possibly be explained by the fact that the ICTY did not focus on Dutch individuals as suspects but only as witnesses, whereas the NIOD report could ultimately be a lead for criminal investigators against Dutch peacekeepers. ${ }^{59}$

Being an exercise of historical orientation, the NIOD report does not zoom in on questions of responsibility. Its overall aim was to contextualize, comprehend and explain and not to offer judgement. ${ }^{60}$ In accordance with this mission, the NIOD displays an awareness of the legal value that certain terms carry throughout its

\footnotetext{
52 NIOD (2002), p. 13.

53 NIOD (2002), p. 17.

54 NIOD (2002), p. 18.

55 NIOD (2002), pp. 20-22.

56 NIOD (2002), pp. 16-17.

57 NIOD (2002), pp. 2972-2973.

58 According to Art. 12 of the Dutch Code of Criminal Procedure, individuals can request the court to order the Public Prosecution Service to open a prosecution. An Art. 12 complaint was lodged regarding the initiation of prosecutions against Karremans and others, but was dismissed. See Mehida MustafićMujić et al. v. Karremans et al., supra n. 2, para. 7.3.1.

59 Ibid.

60 Blom (2002).
} 
report. For instance, it notes that the word 'refugee' may not, legally-technically speaking, be applicable given the internal dimensions of the situation. ${ }^{61}$ Similarly, the report appreciates the distinction between the terms evacuation and deportation and it underscores that a situation of violence and intimidation may render the idea of 'free choice' non-existent. ${ }^{62}$ It subsequently provides a sort of disclaimer indicating that it uses these words without the intention of giving an exact legal appraisal. In a similar vein, the report does not shy away from using the word 'genocide', but it does explicate that it utilizes this burdened word in a non-legal sense and that it adheres to the public use of this word to allude to the fall of Srebrenica. ${ }^{63}$

The report is thus clearly meant to be non-judgemental. Yet, it is tremendously rich in detail and description and it offers a wealth of facts. It may not therefore be surprising that in particular ICTY defence attorneys often spotted useful leads for their defence case. They have invoked the report frequently and in their view the NIOD report is, 'the largest and most thorough study of events related to the fall of Srebrenica'. ${ }^{64}$

\section{The Political and Judicial Reception of the Two Inquiry Reports}

The political reception of the two reports differed markedly. The principal followup at the UN level to the Harland report was the publication of another report. The UN's failure in Srebrenica as recorded in the report of December 1999 precipitated the more general and thematic inquiry undertaken by Brahimi's High-Level Panel. The Brahimi panel charted peacekeeping doctrines and strategies and contrasted those with past experiences and practices to offer a basis for further recommendations. Other than this, the publication of the 1999 UN Srebrenica report had no effective and public political repercussions for the UN, the Member States or individual staff members.

In contrast, the NIOD report had quite dramatic consequences. Upon its presentation, the Dutch government led by Wim Kok resigned. Subsequently, on 5 June 2002, a parliamentary commission was established to make definitive political findings on the actions of the Dutch Parliament, the Dutch government and the military and political leaders responsible before, during and after the events in Srebrenica. This commission concluded in January 2003, inter alia, that the resignation of the Kok II government in April 2002 had indeed been justified. The main substantive conclusions of the report, entitled Mission without peace, were that:

\footnotetext{
61 NIOD (2002), p. 2597. The report also underscored, though, that this finding might have further implications for the status of the safe area vis-à-vis the Republic of Bosnia-Herzegovina and the Republic of Srpska.

62 NIOD (2002), pp. 2598-2599. See on this distinction also the Karremans judgement, supra n. 2.

63 NIOD (2002), p. 2653. See also p. 13 where it is explained that reservations regarding the use of the word genocide are inspired by the wish to prevent conflation with criminal prosecutions.

64 ICTY, The Prosecutor v. Tolimir, Case No. IT-05-88/2-T, Defence Final Trial Brief, 1 October 2012, para. 137.
} 
- Dutchbat had been dispatched to Srebrenica without a clear mandate and prior objections of the military were too easily bypassed;

- Dutchbat did not make attempts to accompany the men until the end when those were evacuated from Potočari;

- Hesitant actions by the French UN General Janvier led to the omission to provide air support when Srebrenica was on the point of being taken;

- General Couzy had created problems for the Minister of Defence by withholding information about war crimes. ${ }^{65}$

In parallel, a separate parliamentary commission investigated decision-making on Dutch participation to peacekeeping missions and concluded that such decisionmaking often took place on the basis of insufficient information. The commission drafted an assessment framework with criteria for future participation. ${ }^{66}$

Similar to this mixed picture of the political follow-up, the judicial reception of both reports is also multifaceted. The relevance and influence of each report to the judicial domain depended on sequencing, the identity of the recipient judicial institution as well as the nature of the case and the prevalent legal questions. Given the chronological circumstance that ICTY investigations and proceedings had been ongoing ever since 1993, the ICTY turned out to be more of a benefactor to the inquiry exercises than a potential beneficiary.

The ICJ judgment in the case of Bosnia $v$. Serbia was rendered well after the publication of the reports, as were the Dutch Srebrenica cases against the Netherlands and the United Nations. Given that the latter case did not reach the merits stage, the reports were not discussed there. Yet in the other Dutch civil cases as well as in the criminal complaints case against Karremans, Franken and Oosterveen, the inquiries were indeed referred to and relied on, albeit with variations. The ICJ referenced both reports, but paid significantly more respect to the UN report. After substantial quotes from the UN report regarding methodology, it concluded, 'The care taken in preparing the report, its comprehensive sources and the independence of those responsible for its preparation all lend considerable authority to it. ${ }^{67}$

In contrast, the Dutch court of first instance in Mothers of Srebrenica $v$. The Netherlands relied much more extensively on the NIOD report. This difference between the ICJ and the Dutch courts obviously originates in their distinct scope of jurisdiction. Moreover, it can be explained by the alignment between the NIOD's extensive treatment of Dutchbat's operations and the focus of litigation before the Dutch courts.

In general, the relevance of inquiry reports for judicial processes can be multifold. For all engaged actors in the courtroom, such reports can fulfil an

\footnotetext{
65 Missie zonder vrede, see supra n. 2, pp. 413 et seq.

66 Parliamentary Records TK 23.591, no. 5 (1999-2000), 4 September 2000 (Vertrekpunt Den Haag).

67 ICJ, Application of the Convention on the Prevention and Punishment of the Crime of Genocide (Bosnia and Herzegovina v. Serbia and Montenegro), Judgment, ICJ Rep. 2007, p. 43, para. 230; see also the Declaration by Judge Keith, p. 352.
} 
informative function sketching a general background of the adjudicated issues. ${ }^{68}$ As indicated, inquiry reports share this informative function with other public sources, also those of an informal nature like NGO reports. In addition to providing general background information, inquiry reports can also be referenced in judgements for more immediately relevant contextual descriptions, for the establishment of simple facts, for the determination of facts that have direct legal bearing, for an appraisal of given facts and situations, or for legal conclusions and findings. Reports may in exceptional situations even have a certain precedential value when their legal reasoning and qualifications are adopted by courts. ${ }^{69}$ In the case of Mothers of Srebrenica $v$. The Netherlands, the court of first instance recognized the different roles that inquiry reports can play. It underlined that the conclusions of both reports were not equally accepted by the parties to the dispute and therefore the court held that it would not involve these conclusions in its judicial decision-making. Yet, it indicated that findings of simple facts in the report could serve as a basis for parts of its judgement. ${ }^{70}$ In reality, of course, the distinction between simple facts, inferences, appraisals and legal conclusions is blurred. And indeed, the court did go further than simply borrowing crude or naked facts. On occasion, it also incorporated conclusions from the inquiries. ${ }^{71}$

In the decision on the criminal complaint against Karremans and others, the court also relied very much on the NIOD report. However, the court indicated that the conclusions from the civil case against the state could not be automatically transferred to a criminal case since the civil case established the knowledge of Dutchbat as such, whose acts were attributable to the state, while the criminal case concerned individual responsibility. ${ }^{72}$ In a similar way, it would be proper to differentiate between the extent to which respective courts can rely on inquiry findings. Given the higher evidentiary thresholds, criminal courts in actual trials might well have to be more reserved towards inquiry facts as a basis for direct legal findings regarding culpability than civil courts in state liability cases. ${ }^{73}$

\section{The Function of Inquiry Exercises in the International Legal Order}

As set out in Sect. 1, the function of inquiry is informed by its subject-matter. Leaving the technical inquiries apart, the function of conflict and security inquiries can be further differentiated on the basis of chronology. Inquiries that operate simultaneously with the scrutinized events have an informative function, and they

\footnotetext{
${ }^{68}$ See e.g., Nuhanović v. Staat der Nederlanden, District Court The Hague, 10 September 2008, ECLI:NL:RBSGR:2008:BF0184, footnotes 3, 4, 5, 6, 7, 8, 9, 10, 14, 15.

$69 \operatorname{Re}$ (2013), pp. 288-290, indicating that the ICTY accepted the test developed by the Commission of Inquiry determining the extent of a commander's responsibility.

70 Stichting Mothers of Srebrenica et al. v. Staat der Nederlanden, District Court of The Hague, 16 July 2014, ECLI:NL:RBDHA:2014:8562, para. 4.8.

71 Ibid., e.g., para. 4.190.

72 Mehida Mustafić-Mujić et al. v. Karremans et al., supra n. 2, para. 12.4.

73 See Jacobs and Stahn (2014).
} 
may also be geared towards influencing the ongoing conflict and sorting a certain preventive effect. They may purposefully and strategically use legal language to prompt action by other actors. The objective of specific prevention no longer plays a role for retrospective inquiries, and there is thus no parallel need for a similar strategic use of international law. In fact, retrospective inquiries may rather display reservation towards the use of international law, as indeed demonstrated by the analysis in Sects. 2 and 3 of the UN and NIOD inquiries. In terms of perspective, retrospective inquiries coincide with legal accountability processes. This simultaneousness requires differentiation so as not to duplicate or commingle and it induces inquiry commissions to adopt a reserved attitude towards international law so as not to pre-empt formal legal findings.

The two mechanisms of inquiry and judicial process do share synergies to the extent that they focus on questions of answerability and accountability. However, while criminal processes focus on questions of guilt and criminal responsibility, inquiries are ultimately predominantly driven by a desire to uncover and understand and to learn lessons, and this may be combined with addressing questions of accountability in a non-legal sense. These inquiry objectives presuppose a certain contextualization of events with a view to highlighting their multifaceted nature. The lenses through which a conflict is deciphered are shaped by the exact mandate of an inquiry exercise but these will always be broader than those of a criminal prosecutor. The NIOD inquiry was special given its particularly wide breath and its historic-scientific nature. Its wide mandate did not offer much guidance as regards the selection of which constituted relevant facts. Indeed, the NIOD understood its task to be: offering 'a reconstruction of events as an intrinsically dynamic historical process with the highest achievable level of accuracy and substantiation' ${ }^{74}$

In contrast to inquiry mechanisms and their underlying aspiration to reconstruct what happened, legal processes primarily respond to a desire for justice, vindication, and redress. These processes, and particularly crime adjudications, decontextualize as they zero in on concrete individuals and are more binary in character. As observed by Van der Wilt in his contribution to this special issue ${ }^{75}$ the construction of reality through legal categories of individual criminal responsibility may have a certain distorting effect. In criminal trials, only a few facts are established, and they are established rigorously. In inquiry processes generally a greater set of facts is offered and these are not tied up to legal categories. Yet the inquiry methodologies are not guided by strict rules of procedure and evidence and inquiry facts are thus constructed in a less scrupulous manner.

In a more generic sense, the mechanism of inquiry may seem to respond to the concerns of some scholars about international criminal processes. ${ }^{76}$ Koskenniemi has underscored the impossibility of reducing conflict to one individual and he questioned the propriety of international criminal law on this ground. ${ }^{77}$ Based on a similar observation, Nollkaemper has argued that individual criminal responsibility

\footnotetext{
74 NIOD (2002), p. 29.

75 Van der Wilt (2015).

76 See generally, Tallgren (2002).

77 Koskenniemi (2002).
} 
is an insufficient response to system criminality and that other legal avenues should be explored to capture the collective nature of the crimes. ${ }^{78}$ Nollkaemper has developed the concept of shared responsibility to better account for the co-existence of different forms of legal responsibility. The inquiries into the fall of Srebrenica indeed demonstrate that responsibility can be dispersed over different actors and that it exists in different shapes and degrees, ranging from criminal to civil and beyond. The Srebrenica inquiries also show that certain forms of involvement are better framed in terms of political and moral responsibility and cannot easily be translated into legal categories. The inquiries paint a picture of what can perhaps be called 'shattered responsibility', since they depict a multilayered web of responsibilities of different levels and categories. As the institutional corollary of this idea of 'shattered responsibility', a case can be made for greater emphasis on non-legal responses to conflict and international crimes so as to render these non-legal forms of responsibility more visible.

Inquiry is a soft mechanism. It does not have the attraction of direct coerciveness, but it may be better attuned than legal processes to grasp the complexity of a situation in its entirety. This is not to say that inquiry should replace international criminal processes but it should rather be seen as a complementary response. Srebrenica occurred in the heyday of international criminal justice. Yet, twenty years later, an understanding has emerged that international criminal justice is in itself not a sufficient response and that it should never be a stand-alone exercise. It must be complemented by other responses. The institution of inquiry may fulfil such a complementary function as it can address societal demands for the accountability of a wider range of actors. The Srebrenica inquiries have demonstrated how such functions can effectively be fulfilled. Underlining the relevance and importance of retrospective inquiries may thus be said to belong to the institutional legacy of Srebrenica.

Acknowledgments I thank Gabriel Webber Ziero and Hilde Roskam for their excellent research assistance.

Open Access This article is distributed under the terms of the Creative Commons Attribution 4.0 International License (http://creativecommons.org/licenses/by/4.0/), which permits unrestricted use, distribution, and reproduction in any medium, provided you give appropriate credit to the original author(s) and the source, provide a link to the Creative Commons license, and indicate if changes were made.

\section{References}

Baudet F (2003) Srebrenica, een veilig gebied. Het laatste woord over de val van een safe area? Het Drama Srebrenica. Geschiedtheoretische beschouwingen over het NIOD-rapport. Tijdschrift voor Geschiedenis 116(2):11-27

Blom JCH (2002) Het NIOD-rapport onevenwichtig en intellectueel gemakzuchtig? Een kwestie van lezen. Int Spect LVI 448-453

78 Nollkaemper (2009). 
Blom JCH, De Graaff BGJ (2003) Het Srebrenica-onderzoek. Een extreem geval van eigentijdse geschiedenis. Het Drama Srebrenica. Geschiedtheoretische beschouwingen over het NIOD-rapport. Tijdschrift voor Geschiedenis 116(2):116-138

Hartmann F (2015) Sang de la Realpolitik. L'affaire Srebrenica. Don Quichotte, Paris

Jacobs D, Stahn C (2014) Human rights fact-finding and international criminal proceedings: towards a polycentric model of interaction. Grotius Centre Working Paper 2014/017-ICL

Koskenniemi M (2002) Between impunity and show trial. Max Planck Yearb UN Law 6:1-35

Lagrou P (2003) Het Srebrenica-rapport en de geschiedenis van het heden. BGMN 118(3):325-336

NIOD (2002) Srebrenica: een 'veilig' gebied; reconstructie, achtergronden, gevolgen en analyse van de val van een safe area. Boom, Amsterdam

Nollkaemper A (2009) System criminality in international law: introduction. In: Nollkaemper A, Van der Wilt H (eds) System criminality in international law. Cambridge University Press, Cambridge

Re D (2013) Fact-finding in the former Yugoslavia: what the Courts did. In: Bergsmo M (ed) Quality control in fact-finding. Torkel Opsahl Academic EPublisher, Florence, pp 279-323

Runia E (2015) Het Srebrenicasyndroom. Amsterdam University Press, Amsterdam

Tallgren I (2002) The sensibility and sense of international criminal law. Eur J Int Law 13(3):561-595

Van den Herik L (2014) An inquiry into the role of commissions of inquiry in international law: navigating the tensions between fact-finding and international law application. Chin J Int Law 13:1-30

Van den Herik L, Harwood C (2015) Sharing the law: the charm of international criminal laws for commissions of inquiry. In: Alston P, Knuckey S (eds) Human rights fact-finding in the 21st century. Oxford University Press, Oxford

Voorhoeve J (2015) Veilige gebieden; falen en slagen bij de bescherming van burgers in oorlog. Atlas Contact, Amsterdam

Van der Wilt H (2015) Srebrenica: on joint criminal enterprise, aiding and abetting and command responsibility. Neth Int Law Rev. doi:10.1007/s40802-015-0036-8 